\title{
Synaptic Targeting and Functional Modulation of GluK1 Kainate Receptors by the Auxiliary Neuropilin and Tolloid-Like (NETO) Proteins
}

\author{
Bryan A. Copits, John S. Robbins, Shanti Frausto, and Geoffrey T. Swanson \\ Department of Molecular Pharmacology and Biological Chemistry, Northwestern University Feinberg School of Medicine, Chicago, Illinois 60611
}

Auxiliary proteins modify the biophysical function and pharmacological properties of ionotropic glutamate receptors and likely are important components of receptor signaling complexes in vivo. The neuropilin and tolloid-like proteins (NETO) 1 and NETO2, two closely related CUB domain-containing integral membrane proteins, were identified recently as auxiliary proteins that slowed GluK2a kainate receptor current kinetics without impacting receptor membrane localization. Here we demonstrate that NETO2 profoundly slows the desensitization rate of GluK1 kainate receptors, promotes plasma membrane localization of transfected receptors in heterologous cells and rat hippocampal neurons, and targets GluK1-containing receptors to synapses. Conversely, the closely related protein NET01 increases the rate of GluK1 receptor desensitization. Incorporation of NETO proteins into kainate receptor-signaling complexes therefore extends the temporal range of receptor gating by over an order of magnitude. The presence of these auxiliary proteins could underlie some of the unusual aspects of kainate receptor function in the mammalian CNS.

\section{Introduction}

Ionotropic glutamate receptors (iGluRs) are integrated into macromolecular signaling complexes that include scaffolding proteins, enzymes, and trafficking chaperone or adaptor proteins (Traynelis et al., 2010). These associations are critical for both constitutive and regulated control of receptor synthesis, assembly, and localization to appropriate sites of action in neurons. In addition, functional diversity of all three types of iGluRs-AMPA, kainate (KAR), and NMDA receptors-is enhanced through association with chaperone and auxiliary proteins that can directly alter receptor biophysical and pharmacological properties as well as synaptic targeting of iGluRs in the CNS.

The relevance of auxiliary proteins to excitatory neurotransmission has been a central focus of research following the characterization of stargazin, the integral membrane protein responsible for the stargazer mouse phenotype (Letts et al., 1998), as the first of a family of transmembrane AMPA receptor regulatory proteins (Chen et al., 2000; Vandenberghe et al., 2005). Significantly less is known regarding the importance of two recently

\footnotetext{
Received Jan. 6, 2011; revised March 30, 2011; accepted April 1, 2011

Author contributions: B.A.C. and G.T.S. designed research; B.A.C., J.S.R., S.F., and G.T.S. performed research; B.A.C. and G.T.S. analyzed data; G.T.S. wrote the paper.

Imaging of fixed neurons was performed at the Northwestern University Cell Imaging Facility and was partially subsidized by National Cancer Institute Grant CCSG P30 CA060553 awarded to the Robert H. Lurie Comprehensive Cancer Center. This study was supported by award R01 NS071952 from the National Institute of Neurological Disorders and Stroke to G.T.S. We thank Drs. William Marszalec and Jack Waters (Northwestern University Feinberg School of Medicine, Chicago, IL) for preparation of cultured hippocampal neurons and technical assistance with live-cell imaging, respectively.

The authors declare no competing financial interests.

Correspondence should be addressed to Dr. Geoffrey T. Swanson at the above address. E-mail: gtswanson@ northwestern.edu.

DOI:10.1523/JNEUROSCI.0100-11.2011

Copyright $\odot 2011$ the authors $\quad 0270-6474 / 11 / 317334-07 \$ 15.00 / 0$
}

characterized NMDA and KAR auxiliary proteins, the neuropilin and tolloid-like proteins (NETO)-1 and NETO2, which are closely related single-pass integral membrane proteins (Stöhr et al., 2002; Ng et al., 2009; Zhang et al., 2009). The GluK2a KAR subunit interacts with the NETO2 protein, and possibly NETO1, and the NETO2 association slows channel gating by several fold without concomitant effects on receptor membrane expression (Zhang et al., 2009). GluN2 NMDA receptors were shown to interact biochemically with NETO1 through an extracellular interaction with one of its two CUB (complement C1r/C1s, Urchin EGF, Bmp1) domains (Ng et al., 2009). Other CUB domain-containing proteins, SOL-1 and LEV-10, also act as critical auxiliary proteins for the GLR-1 glutamate receptor and levasimole-sensitive acetylcholine receptor, respectively, in Caenorhabditis elegans (Gally et al., 2004; Zheng et al., 2004). This conserved motif and other structural elements are therefore common features of a family of ionotropic receptor-associated auxiliary proteins.

In the current study, we examined how NETO proteins impact the function of KARs composed of homomeric assemblies of GluK1 subunits. Analogous receptors largely comprise the population of iGluRs in dorsal root ganglia (DRGs) sensory neurons (Huettner, 1990; Swanson and Heinemann, 1998), where they influence nociceptive transmission (Wu et al., 2007). We found that assembly with NETO1 and NETO2 differentially modify homomeric GluK1 receptor gating, and that NETO2 strongly promoted synaptic localization of GluK1 receptors in hippocampal neurons. These results demonstrate that auxiliary NETO proteins have a significant impact on the function and neuronal distribution of GluK1-containing KARs.

\section{Materials and Methods}

Constructs and materials. Mouse NETO1-hemagglutinin (HA) and rat NETO2 cDNAs were gifts from Michael Salter (University of Toronto, To- 
A

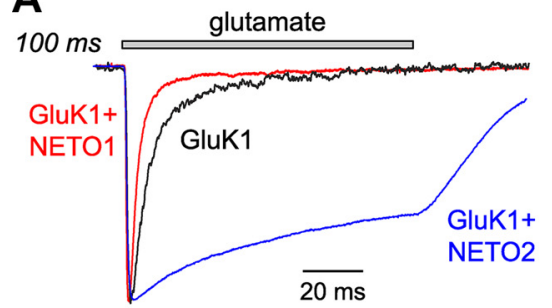

B

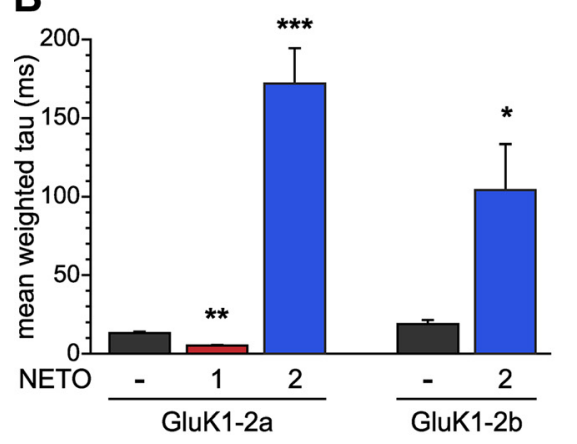

D

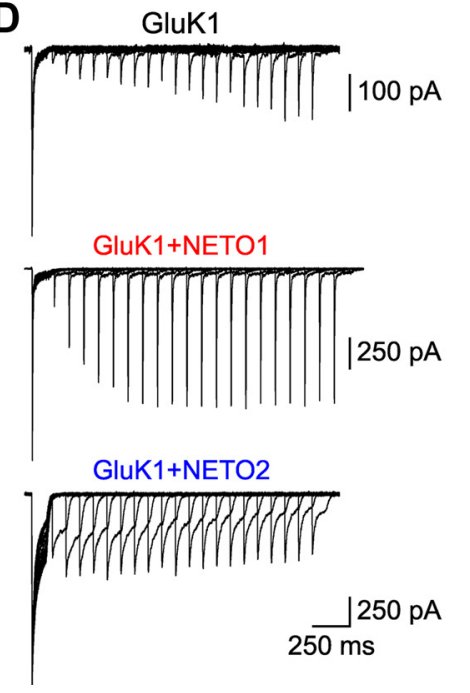

Figure 1. NET0 proteins bidirectionally alter GluK1 kainate receptor desensitization kinetics. $A$, Representative whole-cell current traces from HEK293-T/17 cells expressing GluK1-2a (black), GluK1-2a/NET01 (red), or GluK1-2a/NET02 (blue) receptors. Glutamate (10 mm) was applied for $100 \mathrm{~ms}$ (left) or $1 \mathrm{~s}$ (right). $\boldsymbol{B}$, Weighted desensitization rates measured from currents evoked by $1 \mathrm{~s}$ applications of glutamate to receptors. $C$, Peak current amplitudes measured in response to initial applications of glutamate to receptor-expressing cells. Values shown are mean \pm SEM. Statistical significance is denoted as follows: ${ }^{*} p<0.05 ;{ }^{* *} p<0.01$; and $^{* * *} p<0.001$. D, Recovery from desensitization for GluK1-2a and NETO-containing receptors. In these representative examples, the intervals between paired applications ranged from $50 \mathrm{~ms}$ to $2 \mathrm{~s}$, although longer intervals were also obtained. Current amplitudes from the second application were normalized to their corresponding control currents to determine the time course of recovery from desensitization, which contains data from intervals of $20 \mathrm{~ms}$ to $30 \mathrm{~s}$. GluK1-2a data (gray squares, black fitted curve) and GluK1-2a/NET01 data were best fit with a biexponential recovery curves. GluK1-2a/NET02 receptors were not fully desensitized after control applications, and thus little recovery is observed from plateau amplitude at $\sim 40 \%$ of the peak amplitude. Recovery data for these receptors therefore were fit in the range from 2 to $30 \mathrm{~s}$.

ronto, ON, Canada) and Susumu Tomita (Yale University School of Medicine, New Haven, CT), respectively. NETO1-HA cDNA was mutated to remove the c-terminal HA tag using the Quikchange kit according to the manufacturer's protocol (Agilent Technologies). Yellow fluorescent protein (YFP)-postsynaptic density-95 (PSD-95) cDNA and myc-GluK1 cDNA constructs were generously provided by John Marshall (Brown University, Providence, RI) and Christophe Mulle (University of Bordeaux, Bordeaux, France), respectively. Superecliptic pHluorin (SEP)-GluK1 cDNA was generated by site-directed sequential alteration of GFP residues S147D, N149Q, V163A, S175G, S202F, Q204T, and A206T in GFP-GluK1 cDNA (Miesenböck et al., 1998) and was confirmed to be functional in recordings from transfected HEK293-T/17. The following antibodies were used: mouse antibassoon (ADI-VAM-PS-003; Enzo Life Sciences); mouse anti-HA(H9658; Sigma); mouse anti-myc (11667149001; Roche); rabbit anti-myc (06-549; Millipore); and rabbit anti-NETO2 (HPA013180; Sigma). All other reagents were from Sigma.

Electrophysiology. Cell culture, transfection, whole-cell patch-clamp recording, and fast drug application to receptor-expressing HEK293-T/17 cells were performed as described previously (Vivithanaporn et al., 2007). All cells were held at $-70 \mathrm{mV}$. Rise times (10$90 \%$ ) for whole-cell currents evoked by fast application of glutamate $(10 \mathrm{~mm})$ to transfected cells ranged from 1 to $2 \mathrm{~ms}$. Weighted desensitization rates and relative proportions were calculated from biexponential fits of current decays during $1 \mathrm{~s}$ applications of glutamate using Clampfit10 (Molecular Devices). Recovery rates were calculated from two-component exponential association fits using Origin 7.5 (OriginLab), except for GluK1-2a/NETO2 data, which were fit to a single exponential association with a plateau function in GraphPad 4 (GraphPad Software). Whole-cell voltageclamp recordings from transfected rat hippocampal neurons also were performed as described previously (Gill et al., 2010). EPSCs mediated by KARs (EPSC $\mathrm{KA}_{\mathrm{K}}$ ) in neurons were recorded in the presence of $10 \mathrm{~mm} \mathrm{BaCl}$ containing external solution supplemented with bicuculline $(10 \mu \mathrm{M})$, picrotoxin $(50 \mu \mathrm{M})$, D-AP5 $(50 \mu \mathrm{M})$, and GYKI53655 $(50 \mu \mathrm{M})$ to prevent activation of $\mathrm{GABA}_{\mathrm{A}}, \mathrm{NMDA}$, and AMPA receptors. We verified that these concentrations of antagonists did not inhibit GluK1-2a/NETO2 receptors in recordings from transfected HEK293 cells (data not shown). CNQX was bath applied at the conclusion of each neuronal recording. To analyze spontaneous EPSC $_{\mathrm{KA}}$, segments of current recordings recorded either in the absence or presence of CNQX were analyzed using MiniAnal (Synaptosoft) in a blinded fashion.

Biochemistry. Cell ELISAs, immunoprecipitations, and immunoblots were performed as described previously (Gill et al., 2009).

Imaging. Transfection of cultured rat hippocampal neurons (17-21 d in vitro) prepared from late embryonic pups of either sex, image acquisition on a Zeiss LSM510 META confocal microscope in the Northwestern University Cell Imaging Facility, and calculation of relative plasma membrane expression were performed as described previously (Vivithanaporn et al., 2007). Images were quantified using ImageJ Software. Images were background subtracted, and pixel intensity values of individual slices were summed. Regions of interest were drawn around the entire neuron or soma to compare surface/total distribution. Integrated intensity values for the surface images were divided by the summed intensity values obtained from the surface-labeled and intracellularly labeled channels. Quantitative analysis of colocalized PSD-95 and GluK1 fluorescence in transfected neurons was performed on 5 cells for GluK1 (2423 puncta), 10 cells for GluK1/NETO1 (4469 puncta), and 7 cells for GluK1/NETO2 (3745 puncta).

Statistical analysis. A one-way ANOVA of electrophysiological data using Bartlett's test demonstrated that the SD of both amplitude and tau 
values among GluK1-2a, GluK1-2a/NETO1, and GluK1-2a/NETO2 currents was unequal (amplitude: Bartlett's statistic $=75.5$; tau: Bartlett's statistic $=305.9 ; p<0.001$ in both cases). For that reason, a KruskalWallis test with Dunn's multiple comparisons was used for statistical analysis of this dataset. GluK1-2b and GluK1-2b/NETO2 current properties were compared with an unpaired $t$ test with Welch's correction. Imaging data were assessed using an ANOVA with Bonferroni's post hoc test. Relative membrane expression in cell ELISAs was tested using a two-tailed, unpaired Student's $t$ test. Statistical significance in each case was denoted as follows: ${ }^{\star} p<0.05:{ }^{* *} p<0.01$; and ${ }^{* * *} p<0.001$.

\section{Results}

To determine whether NETO proteins alter homomeric GluK1 receptor function, we recorded glutamate-evoked currents from receptors in the absence and presence of either NETO1 or NETO2 in HEK293-T/17 cells (Fig. 1A). KARs composed of homomeric GluK1-2a or GluK1-2b subunits, which are dissimilar in their C-terminal domains, were examined in whole-cell voltage-clamp recordings. Glutamate (10 $\mathrm{mm}$ ) was fast applied for either $100 \mathrm{~ms}$ or $1 \mathrm{~s}$ (Fig. $1 \mathrm{~A}$, left and right sets of traces, respectively).

As shown in the representative traces, coexpression of NETO proteins altered desensitization rates relative to glutamateevoked currents from GluK1 receptors alone. Surprisingly, NETO1 and NETO2 had opposing effects on receptor kinetics. GluK12a/NETO1 currents desensitized significantly faster on average (red traces), whereas GluK1-2a/NETO2 receptor currents exhibited 13-fold slower desensitization kinetics (blue traces) relative to GluK1-2a receptors lacking auxiliary proteins (black traces). Thus, the mean weighted desensitization rate for GluK1-2a receptors was $12.9 \pm 1.0 \mathrm{~ms}(n=41)$ compared with $5.2 \pm 0.4 \mathrm{~ms}$ $(n=26)$ for GluK1-2a/NETO1 and $172 \pm 22 \mathrm{~ms}$ for GluK1-2a/ NETO2 receptors $(n=29)$ (GluK1-2a vs GluK1-2a/NETO1, $p<$ 0.01; GluK1-2a vs GluK1-2a/NETO2, $p<0.001$ ) (Fig. $1 B$ ). Desensitization of GluK1-2b receptors similarly was slowed by association with NETO2 (GluK1-2b, $19.0 \pm 2.6$ ms; GluK1-2b/ NETO2, $104.1 \pm 29.3 \mathrm{~ms} ; p=0.0125, n=14$ cells each) (Fig. $1 B)$. Currents evoked from GluK1-2a/NETO2 receptors also had an approximately sixfold larger mean peak amplitude than either GluK1-2a or GluK1-2a/NETO1 receptors (GluK1-2a, $415 \pm 77$ pA; GluK1-2a/NETO1, $811 \pm 158$ pA; GluK1-2a/NETO2, $2392 \pm 396$ $\mathrm{pA}$; the latter was significantly different from GluK1-2a alone, $p<$ 0.001 ) (Fig. 1C), and a similar result was obtained with GluK1-2b receptors (GluK1-2b, $339 \pm 90$ pA; GluK1-2b/NETO2, $1818 \pm 417$ $\mathrm{pA} ; p=0.0035)$.

GluK1-2a/NETO2 receptor currents also exhibited a timedependent increase in desensitization rate over a relatively short interval, which was not apparent with GluK2a/NETO2 receptors. Within $3 \mathrm{~min}$ of the first glutamate application, the mean weighted desensitization rate for GluK1-2a/NETO2 receptors increased from $182 \pm 21$ to $142 \pm 24 \mathrm{~ms}(n=11 ; p<0.0059$, paired $t$ test $)$. Desensitization of GluK2a/NETO2 receptors, on the other hand, was constant at $23.1 \pm 4.4 \mathrm{~ms}$ initially and $22.5 \pm 3.9 \mathrm{~ms}$ after $3 \mathrm{~min}(n=14$; $p=0.3948$ ), similar to the rate reported previously (Zhang et al., 2009). The time-dependent change in gating properties may therefore result from cellular processes specific to GluK1-containing receptors, given that we previously reported similar behavior from homomeric GluK1-2a receptors (Swanson and Heinemann, 1998).

The rates of recovery from desensitization of glutamate-evoked currents also differed when GluK1-2a receptors were associated with either NETO1 or NETO2 proteins. Recovery time courses were determined by measuring the relative current amplitudes evoked by paired glutamate applications separated by intervals ranging from 20 $\mathrm{ms}$ to $15 \mathrm{~s}$ (representative traces in Fig. $1 D$ show responses at inter-

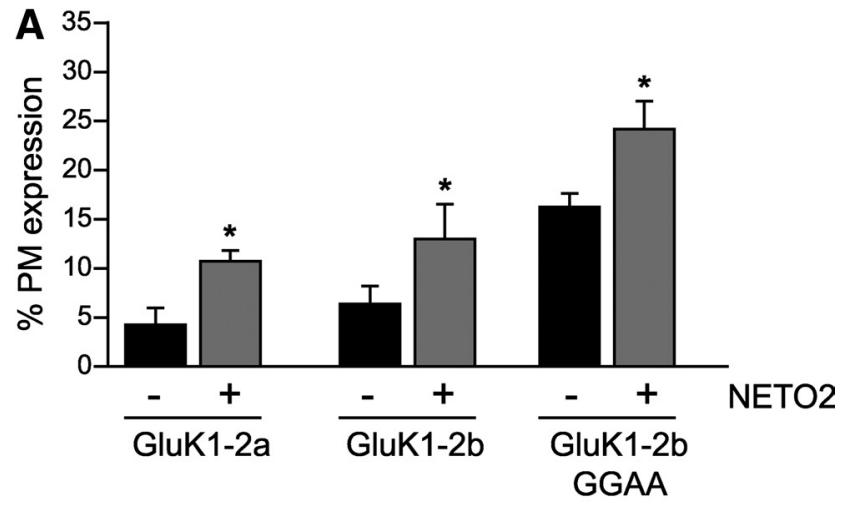

B IP: myc-GluK1-2a
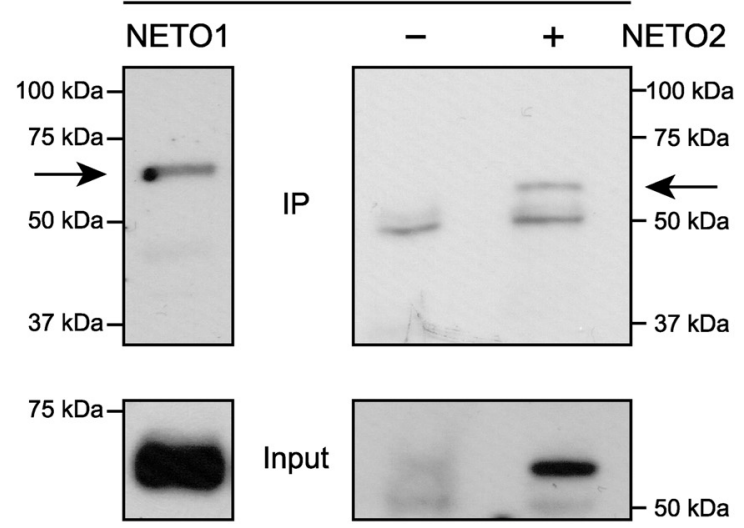

IB: NETO1-HA

IB: NETO2

Figure 2. NETO proteins promote plasma membrane localization through associations with GluK1 subunits. A, Column graph showing data from cell ELISA experiments to determine the relative expression of myc-tagged receptor proteins on the plasma membrane of transfected COS-7 cells. Values shown are mean \pm SEM. Statistical significance is denoted as ${ }^{*} p<0.05 . \boldsymbol{B}$, Coimmunoprecipitation of myc-GluK1 and NET0 proteins from transfected COS-7 cells. Bottom confirm expression of NET01 and NETO2 in the transfected cells.

vals from $50 \mathrm{~ms}$ to $2 \mathrm{~s}$ ). GluK1-2a receptor recovery was described with a biexponential time course with tau values of $18 \mathrm{~ms}$ and $5.1 \mathrm{~s}$ (10 and $90 \%$ of the recovery, respectively, $n$ ranged from 3 to 16 recordings at each interval) (Fig. $1 D)$, similar to that reported previously (Swanson and Heinemann, 1998). In contrast, GluK1-2a/ NETO1 receptor currents recovered from desensitization significantly faster (tau values of $301 \mathrm{~ms}$ and $1.7 \mathrm{~s}, 62$ and 38\% of the recovery time course, respectively; $n=4-11$ recordings at each interval). NETO2-containing receptors were only partially desensitized at the termination of the applications, and the receptors did not exhibit any greater recovery of the peak current above the plateau amplitude until the intervals were $>2$ s. Recovery of desensitized receptors was therefore quite slow, and fitting of the recovery data with a single exponential function yielded a tau value of $5.7 \mathrm{~s}$, which was not different from the slow component of recovery for GluK1 receptors. In summary, GluK1-2a association with NETO1 speeds desensitization and subsequent recovery, whereas NETO2 primarily slows entry into desensitized states.

We determined how much of the NETO-dependent increase in peak current amplitude in Figure $1 C$ could be accounted for by the presence of more receptors on the plasma membrane by measuring the relative surface expression of GluK1-2a, GluK1-2b, and GluK1-2b(GGAA), a mutant receptor subunit lacking an ER retention motif (Ren et al., 2003), in the absence and presence of NETO2 (Fig. 2A). Cell ELISAs showed that GluK1 receptors are 

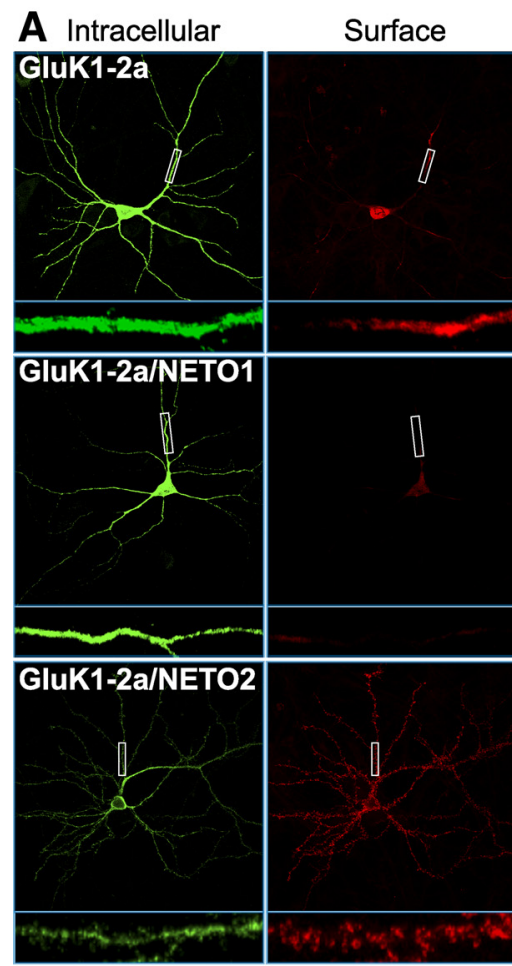

D
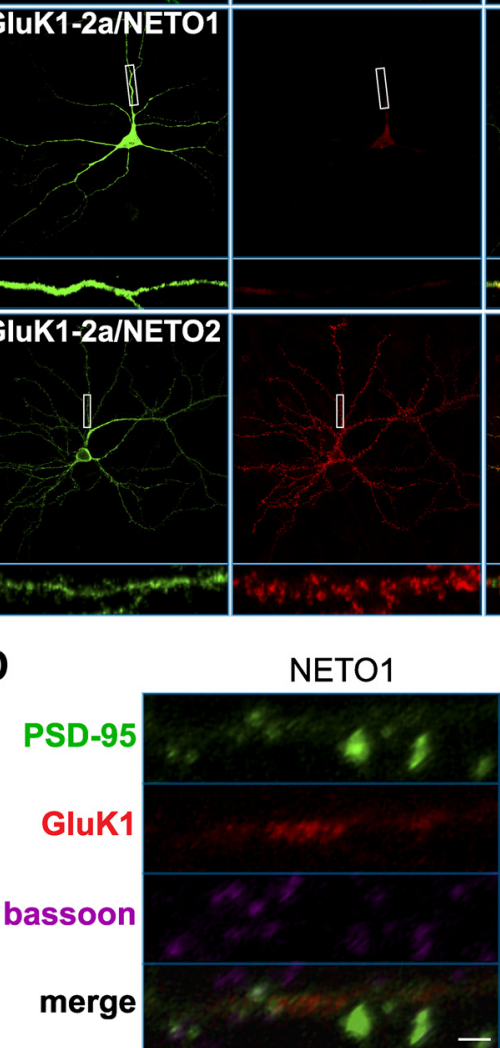

Overlay
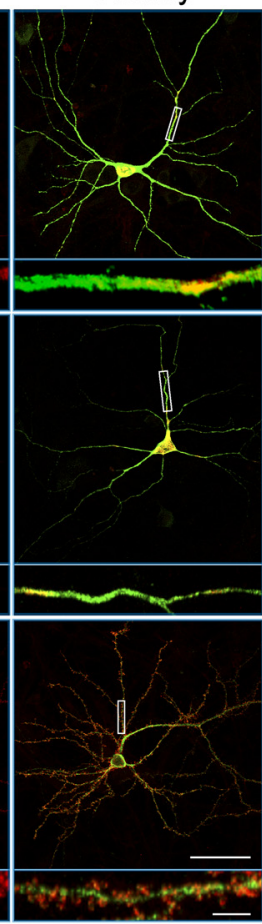

B

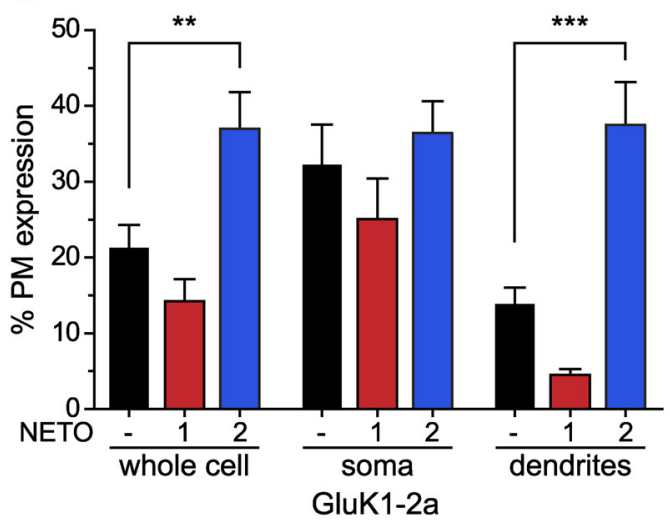

C

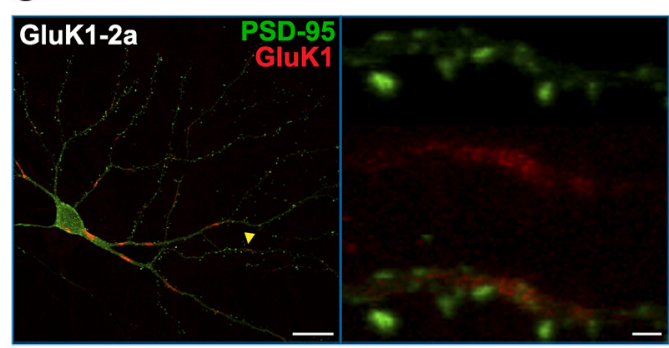

E Synaptic localization of Gluk1
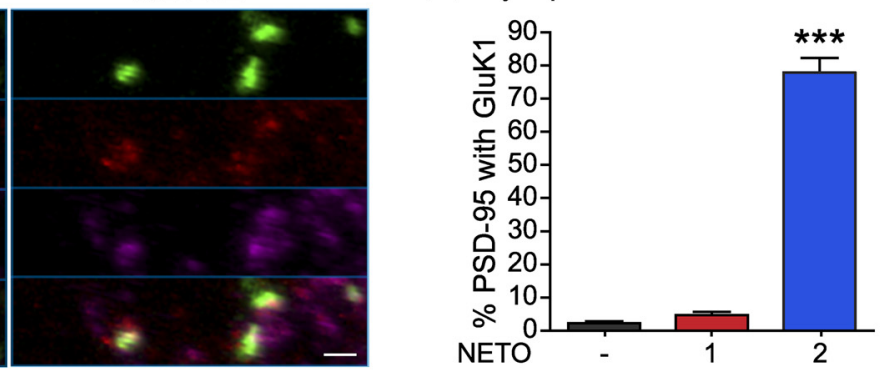

Figure 3. NET02 alters the distribution of GluK1 receptors in hippocampal neurons. A, Representative images from cultured hippocampal neurons transfected with myc-GluK1-2a alone or with either NET01 or NET02. Plasma membrane (red) and intracellular (green) myc-GluK1 proteins were differentially labeled before and after permeabilization, respectively. Expanded images on the bottom of each panel are taken from the area indicated by white rectangles. Scale bars: $20 \mu \mathrm{m}$; inset, $4 \mu \mathrm{m}$. B, Quantitation of relative plasma membrane (PM) expression as calculated from the ratio of red to total (red + green) fluorescence intensity. Ratios were calculated for entire neurons (first two columns) or for the somatic and dendritic compartments separately (second and third pairs of columns). Values shown are mean \pm SEM. Statistical significance is denoted as ${ }^{*} p<0.05$. C, Representative image from a neuron transfected with myc-GluK1-2a (surface expressed myc labeled in red) and YFP-PSD-95 (green) showing patchy distribution of the receptor on dendritic shafts rather than within spines. D, Representative images of dendrites from neurons transfected with myc-GluK1-2a, YFP-PSD-95, and either NET01 or NET02. Anti-myc labeling of neurons before permeabilization localizes GluK1 receptors on the plasma membrane (red), YFP-PSD-95 labels postsynaptic densities (green), and anti-bassoon labeling identifies presynaptic terminals. GluK1-2a is colocalized to synaptic sites positive for PSD-95 and bassoon only in the presence of NET02. Scale bar, $1 \mu \mathrm{m}$. E, Quantification of the percentage of YFP-PSD-95 puncta that also contain myc-GluK1-2a fluorescence in neurons transfected with GluK1-2a alone or with either NET01 or NET02. Values shown are mean $\pm \mathrm{SEM}$. Statistical significance is denoted as ${ }^{* * *} p<0.001$.

expressed at very low levels on the plasma membrane of transfected COS-7 cells under basal conditions (GluK1-2a, $4.3 \pm 1.7 \%$; GluK1-2b, $6.4 \pm 1.8 \% ; n=5$ and 7, respectively). Coexpression with NETO2 increased relative surface localization to $10.8 \pm$ $1.1 \%$ for GluK1-2a/NETO2 and $13.0 \pm 3.5 \%$ for GluK1-2b/ NETO2 ( $p<0.05$, paired $t$ test). The auxiliary protein also promoted surface localization of GluK1-2b(GGAA) receptors in COS-7 cells from $16.3 \pm 1.4 \%$ to $24 \pm 2.9 \%(p=0.014$, paired $t$ test). These modest increases in protein localization, while significant, are not sufficient to fully account for the fivefold to sixfold enhancement of peak current amplitudes. Thus, NETO2 might also enhance intrinsic aspects of channel function, such as the single-channel conductance or probability of channel opening, as occurs with GluK2a receptors assembled with NETO2 (Zhang et al., 2009).
The association between myc-tagged GluK1-2a and either HA-tagged NETO1 or untagged NETO2 proteins next was confirmed biochemically in coimmunoprecipitation experiments from transfected COS-7 cells. As expected, immunoprecipitation of myc-GluK1-2a protein with anti-myc antibody coprecipitated HA-NETO1 or NETO2 auxiliary proteins when the proteins were coexpressed, as verified in Western blots (Fig. $2 \mathrm{~B}$ ). Figure 2B, bottom, confirms expression of the NETO proteins through immunoblotting of lysate proteins with either anti-HA or antiNETO2 antibody. GluK1 receptors therefore assemble into macromolecular complexes with NETO proteins.

We further found that NETO2 promoted plasma membrane localization and redistributed GluK1-containing KARs to synapses in transfected hippocampal neurons. Myc-GluK1-2a receptors on the cell surface were predominantly restricted to the 
somatic compartment and patches on principal dendritic processes when expressed alone in cultured hippocampal neurons (Fig. $3 A$, red panel) (Kayadjanian et al., 2007), despite extensive intracellular localization within dendrites (Fig. $3 A$, green panel) and the likely presence of endogenous KAR subunits (Ruano et al., 1995; Jaskolski et al., 2004). A similar pattern of distribution was observed when GluK1-2a was combined with NETO1 (Fig. 3A). In contrast, coexpression with NETO2 enhanced plasma membrane expression of GluK1-2a and greatly increased dendritic localization, producing a distinct punctate distribution suggestive of substantial accumulation in dendritic spines (Fig. 3A, higher-magnification insets). Quantitation of the relative plasma membrane expression average over entire neurons confirmed that the proportion of GluK1-2a receptor on the membrane increased significantly in the presence of NETO2 but not NETO1 (GluK1-2a: $21.3 \pm 3.0 \%$; GluK1-2a/NETO1:14.3 \pm 2.9\%; GluK1-2a/NETO2: $37.0 \pm$ $4.8 \%$, respectively, $n=15,12$, and 14 neurons, respectively; $p<$ 0.01 by ANOVA with Bonferroni's post hoc test) (Fig. $4 B$ ). Analysis of somatic versus dendritic domains in these images revealed that the new distribution pattern could be ascribed to increases in the proportion of dendritic GluK1-2a receptors localized to the plasma membrane (from a mean of $13.9 \pm 2.2 \%$ for GluK1-2a alone to $37.5 \pm 5.6 \%$ with NETO2; $p<0.001)$ rather than a change in somatic receptor membrane localization (Fig. $3 B$ ). NETO1, in contrast, did not promote redistribution of GluK1-2a into dendrites. Distribution of intracellular GluK1-2a receptors was not altered by either NETO1 or NETO2 coexpression (data not shown).

Colocalization of plasma membrane myc-GluK1-2a receptors with exogenous PSD-95, which distributes to postsynaptic sites, and endogenous bassoon, a presynaptic marker, confirmed that the GluK1 assembled with NETO2 accumulated in dendritic spines. Myc-GluK1-2a transfected alone did not overlap with coexpressed YFP-PSD-95 (Fig. 3C). In contrast, myc-GluK1-2a coexpressed with NETO2 exhibited strong colocalization with YFP-PSD-95 and bassoon (Fig. 3D). NETO1 failed to redistribute myc-GluK1-2a receptors to synapses, consistent with the lack of punctate staining in the previous set of experiments. Quantitation of the percentage of YFP-PSD-95-positive puncta that also contained myc-GluK1 revealed that $78.4 \pm 4.4 \%$ of postsynaptic densities contained the receptor when NETO2 was present, compared with just $2.2 \pm 0.6 \%$ for GluK1-2a alone and $4.7 \pm 0.9 \%$ for GluK1-2a/NETO1-expressing neurons (GluK1-2a: $n=5$ cells and 2423 puncta; GluK1-2a/NETO1: $n=10$ cells and 4469 puncta; GluK1-2a/NETO2: $n=7$ cells and 3745 puncta; $p<$ 0.001 vs GluK1-2a alone using ANOVA). Thus, NETO2, but not NETO1, acts as a chaperone for GluK1 expression within dendrites, delivering the receptor to sites of synaptic contact in cultured hippocampal neurons.

The striking redistribution of GluK1-2a protein to synapses prompted us to attempt to record EPSC $_{\mathrm{KA}}$, which has not been possible previously in cultured hippocampal neurons (Lerma et al., 1997; Zhang et al., 2009). To increase the likelihood of identifying neurons with synaptic KARs, we generated a SEP-tagged GluK1-2a construct, which fluoresces only at neutral $\mathrm{pH}$, and visualized live
B

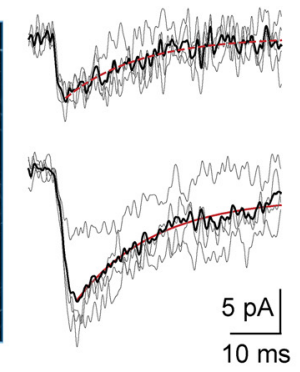

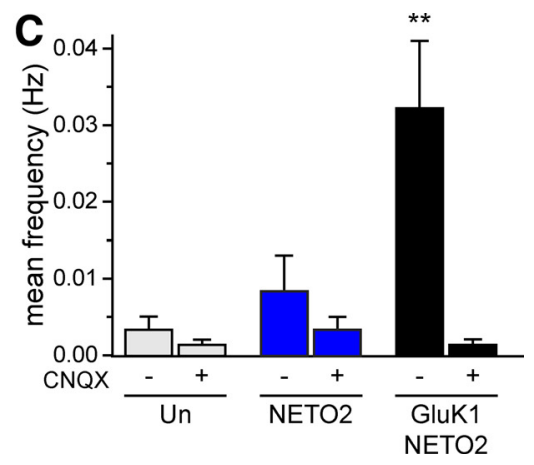

Figure 4. Synaptic kainate receptor currents in hippocampal neurons transfected with SEP-GluK1-2a and NETO2.A, An image of a live hippocampal neuron in culture expressing SEP-GluK1-2a and NETO2. Fluorescence arises from receptors exposed to neutral pH on the analyzed blind before and during application of CNQX (50 $\mu \mathrm{M})$, which inhibits KARs, to validate the detected events as bona fide EPSC $\mathrm{KA}_{\text {. }}$ atistical significance is denoted as ${ }^{* *} p<0.01$.

transfected neurons under epifluorescence. SEP-GluK1-2a receptors were confirmed as functional in recordings from transfected HEK293-T/17 cells (data not shown). Neurons cotransfected with SEP-GluK1-2a and NETO2 were readily identified by the strong GFP fluorescence throughout dendrites, which arises predominantly from plasma membrane receptors (Fig. 4, representative image from a live cell).

While initially we were unable to detect EPSC $_{\mathrm{KA}}$ in whole-cell patch-clamp recordings performed from transfected hippocampal neurons expressing SEP-GluK1-2a and NETO2 $(n=10)$, EPSC $_{\mathrm{KA}}$ neurons were successfully elicited by addition of $10 \mathrm{~mm}$ $\mathrm{BaCl}$ to the external solution to increase release probability. Spontaneous synaptic events from GluK1-2a/NETO-expressing cells occurred at low frequency but were largely absent from untransfected or NETO2-transfected neurons. Representative EPSC $_{\mathrm{KA}}$ neurons from two cells are shown in Figure 4; gray traces are individual synaptic currents, and the solid black traces are the averaged EPSC $_{\mathrm{KA}}$ neurons. Segments of $\mathrm{EPSC}_{\mathrm{KA}}$ recordings both before and after addition of CNQX were analyzed blind to the treatment; the mean frequencies for these data are shown in Figure 4. The frequency of events in the GluK1-2/NETO2 neurons was quite low $(0.032 \pm 0.009 \mathrm{~Hz})$ but nevertheless significantly higher than the frequency in the presence of CNQX $(0.001 \pm$ $0.001 \mathrm{~Hz} ; n=7 ; p<0.01$, paired $t$ test); the latter likely represents our false-positive rate in fitting the small-amplitude synaptic currents. The mean amplitude of GluK1-2a/NETO2 EPSC $_{\mathrm{KA}}$ was $20.0 \pm 5.6 \mathrm{pA}$, although in most cells the currents were of smaller

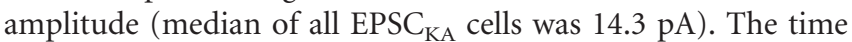
constant of decay for averaged traces generated by alignment of the $10-90 \%$ rise of individual events in each cell was $13.3 \pm 2.3$ $\mathrm{ms}$. In sum, these data demonstrate that $\mathrm{EPSC}_{\mathrm{KA}}$ neurons are detectable under conditions of elevated release probability when GluK1-2a and NETO2 are expressed in cultured hippocampal neurons.

\section{Discussion}

These results confirm and extend the hypothesis that associations with the CUB domain-containing integral proteins NETO1 and NETO2 constitute important determinants of KAR function. We found in the current study that both NETO1 and NETO2 profoundly altered desensitization and recovery kinetics of recombinant GluK1 receptors. To our surprise, however, the effect of the 
two closely related auxiliary proteins on GluK1 function and distribution was highly divergent: NETO1 sped up desensitization and reduced neuronal membrane localization whereas NETO2 slowed receptor desensitization and promoted plasma membrane localization in both heterologous cells and neurons. Furthermore, NETO2 strongly enhanced accumulation of GluK1 receptors in postsynaptic densities, resulting in infrequent but detectable $\mathrm{EPSC}_{\mathrm{KA}}$. Thus, NETO proteins likely modify the function of both GluK1 - and GluK2-containing receptors in the nervous system, and regulation of assembly with NETO proteins could serve as a mechanism for fine-tuning KAR signaling. A clearer understanding of how these and other KAR auxiliary proteins, such as the KAR-interacting protein for GluR6 (KRIP6) (Laezza et al., 2007), modify receptor gating and engage neuronal targeting systems will facilitate elucidation of the diverse roles played by KARs in the CNS and peripheral nervous system.

The impact of NETO proteins on KAR function and localization appears to be subunit dependent. Most obviously, rather than slowing kinetics, coassembly with NETO1 increased the rate of desensitization from a mean time constant of $13 \mathrm{~ms}$ (GluK1-2a) to $5 \mathrm{~ms}$ (GluK1-2a/NETO1). With GluK2a receptors, however, NETO1 enhanced KAR steady-state currents in two-electrode voltage-clamp recordings from Xenopus oocytes, albeit to a lesser degree than NETO2, suggesting that the two auxiliary proteins had analogous effects on KAR function (Zhang et al., 2009). NETO2, on the other hand, slowed the GluK1 desensitization rate by over an order of magnitude, a similar but more substantial change in kinetics than that observed with GluK2a receptors. The rate of recovery from desensitization of GluK1/NETO1 receptors also was significantly faster than homomeric GluK1 receptors, with the majority of the receptors recovering within $1 \mathrm{~s}$ of activation. The NETO proteins therefore have a bidirectional and substantial impact on homomeric GluK1 receptor function.

NETO2 altered neuronal localization of GluK1-containing receptors in hippocampal neurons, promoting plasma membrane expression and causing the receptors to accumulate in postsynaptic densities, resulting in functional synaptic currents. GluK1 is predominantly expressed by interneurons in the hippocampus (Bureau et al., 1999; Paternain et al., 2000), which also contain NETO1 mRNA (Michishita et al., 2004; Ng et al., 2009); in these neurons, EPSC $_{\mathrm{KA}}$ kinetics are relatively fast compared with those at mossy fiber-CA3 pyramidal cell synapses (Castillo et al., 1997; Vignes and Collingridge, 1997; Cossart et al., 1998; Frerking et al., 1998), consistent with the effect of NETO1 on GluK1 receptor gating. Mossy fiber KARs are likely composed of GluK2 (Mulle et al., 1998), in combination with GluK4 and GluK5 subunits (Contractor et al., 2003; Fernandes et al., 2009) and further could incorporate either NETO1 or NETO2 based on the expression of both auxiliary proteins in CA3 (Michishita et al., 2004; $\mathrm{Ng}$ et al., 2009). The EPSC $_{\mathrm{KA}}$ we observed in transfected hippocampal neurons decayed at a faster rate than that at mossy fiber-CA3 pyramidal neuron synapses in brain slice preparations (time constants of 13 vs 60-100 ms, respectively) (Castillo et al., 1997; Cossart et al., 2002; Contractor et al., 2003), which likely arises from divergent synaptic structure, molecular composition, and expression of distinct synaptic KARs in the two preparations. It remains to be determined how NETO2 promotes surface expression and synaptic accumulation of GluK1 receptors at a mechanistic level and the importance of subunit-dependent alterations in KAR gating by NETO proteins to neuronal KAR signaling. Furthermore, differential association between NETO proteins and important scaffolding proteins such as PSD-95 could addi- tionally contribute to the highly compartmentalized and diverse localization of KARs in the CNS.

KARs have been implicated in specific modalities of nociceptive transmission (Wu et al., 2007). GluK1 subunits comprise the principal glutamate receptor subunit expressed by smalldiameter sensory neurons (Partin et al., 1993), and DRG glutamate receptor currents have many kinetic and pharmacological similarities to homomeric GluK1 receptor currents with minor contributions from GluK4- or GluK5-containing receptors (Huettner, 1990; Swanson and Heinemann, 1998). NETO1 and NETO2 mRNAs are expressed highly in DRG neurons (Allen Brain Atlas, http://mouse.brain-map.org) and therefore could contribute to the receptor signaling complex and control of nociceptive transmission. However, KAR currents evoked by glutamate from acutely isolated DRG neurons differ from NETO-containing GluK1 receptors in at least two substantive aspects (Swanson and Heinemann, 1998). The neuronal currents desensitize rapidly, which was not observed for GluK1 in the presence of NETO2, and recover with a relatively slow time course, unlike NETO1containing receptors. Thus, our results are more consistent with the hypothesis that DRG kainate currents are composed of GluK1 receptors lacking NETO1 and NETO2. It also is possible that the auxiliary proteins serve to target GluK1-containing receptors to either sites of action in the spinal cord or to peripheral nerve endings, and recording from acutely dissociated neurons (lacking processes) biases our analysis toward NETO-less KARs. It will be of interest to test the ideas in future experiments with the NETO knock-out animals (Ng et al., 2009) or acute knock-down strategies (Zhang et al., 2009). If either of these manipulations reduces KAR function in sensory neurons, it is likely that pain transmission will be attenuated in a fashion similar to that produced by GluK1 gene targeting or pharmacological inhibition (Wu et al., 2007).

In summary, we found that NETO proteins fundamentally alter the function and neuronal localization of GluK1-containing KARs. These results serve as a basis for further elucidation of mechanisms underlying these actions and additional roles for the auxiliary proteins, which could include serving as adaptor proteins or targets of second messenger signaling systems that influence KAR function in the CNS.

\section{References}

Bureau I, Bischoff S, Heinemann SF, Mulle C (1999) Kainate receptormediated responses in the CA1 field of wild-type and GluR6-deficient mice. J Neurosci 19:653-663.

Castillo PE, Malenka RC, Nicoll RA (1997) Kainate receptors mediate a slow postsynaptic current in hippocampal CA3 neurons. Nature 388:182-186.

Chen L, Chetkovich DM, Petralia RS, Sweeney NT, Kawasaki Y, Wenthold RJ, Bredt DS, Nicoll RA (2000) Stargazin regulates synaptic targeting of AMPA receptors by two distinct mechanisms. Nature 408:936-943.

Contractor A, Sailer AW, Darstein M, Maron C, Xu J, Swanson GT, Heinemann SF (2003) Loss of kainate receptor-mediated heterosynaptic facilitation of mossy- fiber synapses in KA2 ${ }^{-1-}$ mice. J Neurosci 23:422-429.

Cossart R, Esclapez M, Hirsch JC, Bernard C, Ben-Ari Y (1998) GluR5 kainate receptor activation in interneurons increases tonic inhibition of pyramidal cells. Nat Neurosci 1:470-478.

Cossart R, Epsztein J, Tyzio R, Becq H, Hirsch J, Ben-Ari Y, Crépel V (2002) Quantal release of glutamate generates pure kainate and mixed AMPA/ kainate EPSCs in hippocampal neurons. Neuron 35:147-159.

Fernandes HB, Catches JS, Petralia RS, Copits BA, Xu J, Russell TA, Swanson GT, Contractor A (2009) High-affinity kainate receptor subunits are necessary for ionotropic but not metabotropic signaling. Neuron 63:818-829.

Frerking M, Malenka RC, Nicoll RA (1998) Synaptic activation of kainate receptors on hippocampal interneurons. Nat Neurosci 1:479-486.

Gally C, Eimer S, Richmond JE, Bessereau JL (2004) A transmembrane pro- 
tein required for acetylcholine receptor clustering in Caenorhabditis elegans. Nature 431:578-582.

Gill MB, Vivithanaporn P, Swanson GT (2009) Glutamate binding and conformational flexibility of ligand-binding domains are critical early determinants of efficient kainate receptor biogenesis. J Biol Chem 284:14503-14512.

Gill MB, Frausto S, Ikoma M, Sasaki M, Oikawa M, Sakai R, Swanson GT (2010) A series of structurally novel heterotricyclic alpha-amino-3hydroxyl-5-methyl-4-isoxazole-propionate receptor-selective antagonists. Br J Pharmacol 160:1417-1429.

Huettner JE (1990) Glutamate receptor channels in rat DRG neurons: activation by kainate and quisqualate and blockade of desensitization by Con A. Neuron 5:255-266.

Jaskolski F, Coussen F, Nagarajan N, Normand E, Rosenmund C, Mulle C (2004) Subunit composition and alternative splicing regulate membrane delivery of kainate receptors. J Neurosci 24:2506-2515.

Kayadjanian N, Lee HS, Piña-Crespo J, Heinemann SF (2007) Localization of glutamate receptors to distal dendrites depends on subunit composition and the kinesin motor protein KIF17. Mol Cell Neurosci 34:219-230.

Laezza F, Wilding TJ, Sequeira S, Coussen F, Zhang XZ, Hill-Robinson R, Mulle C, Huettner JE, Craig AM (2007) KRIP6: a novel BTB/kelch protein regulating function of kainate receptors. Mol Cell Neurosci 34:539-550.

Lerma J, Morales M, Vicente MA, Herreras O (1997) Glutamate receptors of the kainate type and synaptic transmission. Trends Neurosci 20:9-12.

Letts VA, Felix R, Biddlecome GH, Arikkath J, Mahaffey CL, Valenzuela A, Bartlett FS 2nd, Mori Y, Campbell KP, Frankel WN (1998) The mouse stargazer gene encodes a neuronal $\mathrm{Ca} 2+$-channel gamma subunit. Nat Genet 19:340-347.

Michishita M, Ikeda T, Nakashiba T, Ogawa M, Tashiro K, Honjo T, Doi K, Itohara S, Endo S (2004) Expression of Btcl2, a novel member of Btcl gene family, during development of the central nervous system. Brain Res Dev Brain Res 153:135-142.

Miesenböck G, De Angelis DA, Rothman JE (1998) Visualizing secretion and synaptic transmission with $\mathrm{pH}$-sensitive green fluorescent proteins. Nature 394:192-195.

Mulle C, Sailer A, Pérez-Otaño I, Dickinson-Anson H, Castillo PE, Bureau I, Maron C, Gage FH, Mann JR, Bettler B, Heinemann SF (1998) Altered synaptic physiology and reduced susceptibility to kainate-induced seizures in GluR6-deficient mice. Nature 392:601-605.

Ng D, Pitcher GM, Szilard RK, Sertié A, Kanisek M, Clapcote SJ, Lipina T, Kalia LV, Joo D, McKerlie C, Cortez M, Roder JC, Salter MW, McInnes
RR (2009) Neto1 is a novel CUB-domain NMDA receptor-interacting protein required for synaptic plasticity and learning. PLoS Biol 7:e41.

Partin KM, Patneau DK, Winters CA, Mayer ML, Buonanno A (1993) Selective modulation of desensitization at AMPA versus kainate receptors by cyclothiazide and concanavalin A. Neuron 11:1069-1082.

Paternain AV, Herrera MT, Nieto MA, Lerma J (2000) GluR5 and GluR6 kainate receptor subunits coexist in hippocampal neurons and coassemble to form functional receptors. J Neurosci 20:196-205.

Ren Z, Riley NJ, Needleman LA, Sanders JM, Swanson GT, Marshall J (2003) Cell Surface Expression of GluR5 Kainate Receptors Is Regulated by an Endoplasmic Reticulum Retention Signal. J Biol Chem 278:52700-52709.

Ruano D, Lambolez B, Rossier J, Paternain AV, Lerma J (1995) Kainate receptor subunits expressed in single cultured hippocampal neurons: molecular and functional variants by RNA editing. Neuron 14:1009-1017.

Stöhr H, Berger C, Fröhlich S, Weber BH (2002) A novel gene encoding a putative transmembrane protein with two extracellular CUB domains and a low-density lipoprotein class A module: isolation of alternatively spliced isoforms in retina and brain. Gene 286:223-231.

Swanson GT, Heinemann SF (1998) Heterogeneity of homomeric GluR5 kainate receptor desensitization expressed in HEK293 cells. J Physiol 513:639-646.

Traynelis SF, Wollmuth LP, McBain CJ, Menniti FS, Vance KM, Ogden KK, Hansen KB, Yuan H, Myers SJ, Dingledine R (2010) Glutamate receptor ion channels: structure, regulation, and function. Pharmacol Rev 62: 405-496.

Vandenberghe W, Nicoll RA, Bredt DS (2005) Stargazin is an AMPA receptor auxiliary subunit. Proc Natl Acad Sci U S A 102:485-490.

Vignes M, Collingridge GL (1997) The synaptic activation of kainate receptors. Nature 388:179-182.

Vivithanaporn P, Lash LL, Marszalec W, Swanson GT (2007) Critical roles for the M3-S2 transduction linker domain in kainate receptor assembly and post-assembly trafficking. J Neurosci 27:10423-10433.

Wu LJ, Ko SW, Zhuo M (2007) Kainate receptors and pain: from dorsal root ganglion to the anterior cingulate cortex. Curr Pharm Des 13:1597-1605.

Zhang W, St-Gelais F, Grabner CP, Trinidad JC, Sumioka A, MorimotoTomita M, Kim KS, Straub C, Burlingame AL, Howe JR, Tomita S (2009) A transmembrane accessory subunit that modulates kainate-type glutamate receptors. Neuron 61:385-396.

Zheng Y, Mellem JE, Brockie PJ, Madsen DM, Maricq AV (2004) SOL-1 is a CUB-domain protein required for GLR-1 glutamate receptor function in C. elegans. Nature 427:451-457. 